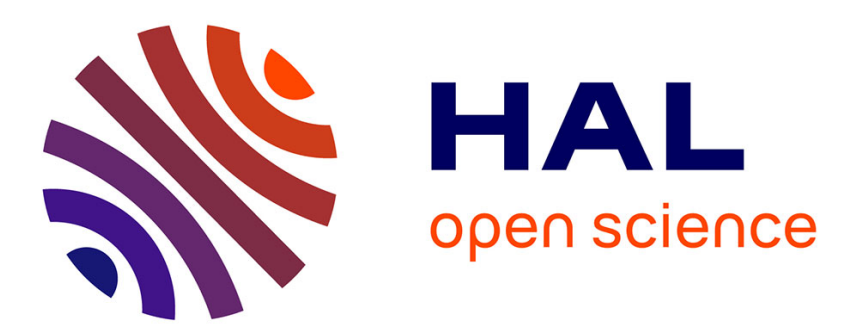

\title{
A Twenty-Year Citation Analysis of the Knowledge Outflow and Inflow Patterns from the Journal of Product Innovation Management
}

\author{
Shikhar Sarin, Christophe Haon, Mustapha Belkhouja
}

\section{To cite this version:}

Shikhar Sarin, Christophe Haon, Mustapha Belkhouja. A Twenty-Year Citation Analysis of the Knowledge Outflow and Inflow Patterns from the Journal of Product Innovation Management. Journal of Product Innovation Management, 2019, 35 (6), pp.854-863. hal-01951637

\author{
HAL Id: hal-01951637 \\ https://hal.science/hal-01951637
}

Submitted on 11 Dec 2018

HAL is a multi-disciplinary open access archive for the deposit and dissemination of scientific research documents, whether they are published or not. The documents may come from teaching and research institutions in France or abroad, or from public or private research centers.
L'archive ouverte pluridisciplinaire HAL, est destinée au dépôt et à la diffusion de documents scientifiques de niveau recherche, publiés ou non, émanant des établissements d'enseignement et de recherche français ou étrangers, des laboratoires publics ou privés. 


\title{
A Twenty-Year Citation Analysis of the Knowledge Outflow and Inflow Patterns from the Journal of Product Innovation Management
}

\author{
Shikhar Sarin, Christophe Haon, and Mustapha Belkhouja
}

Since its inception in 1984, an emphasis on cross-functionality and interdisciplinary research was encrypted into the DNA of the Journal of Product and Innovation Management (JPIM). This essay explores the extent to which the journal has served as a platform for exchange of ideas between different disciplines by examining knowledge outflow and inflow with other scientific journals and disciplines over a 20-year period (1994-2013). Based on an extensive bibliometric database, we gain insights about how JPIM has evolved. We show that the journal has become a gatekeeper, importing knowledge mostly from the marketing and management literatures, and exporting knowledge to the technology and innovations management and the operations management domains.

$\mathrm{S}$ ince its launch in 1984 the Journal of Product Innovation Management (JPIM) has come to be regarded as one of the premier journals in the management of technology and innovation (Linton and Thongpapnl, 2004; Sarin, Haon, and Belkhouja, 2018; Shafiq, 2013). JPIM's growing stature is further underscored by the journal recording an Impact Factor of 4.305 in 2017 - the highest in its history (https://onlinelibrary.wiley.com/journal/15405885).

JPIM's aims and scope describes its mandate as:

The Journal of Product Innovation Management is an interdisciplinary, international journal that seeks to advance our theoretical and managerial knowledge of product and service development. The journal publishes original articles on organizations of all sizes (start-ups, small-medium enterprises, large) and from the consumer, business-to-business, and institutional domains. The journal is receptive to all types of quantitative and qualitative methodologies. Authors across the world from diverse disciplines and functional perspectives are welcome to submit to the journal. (https:// onlinelibrary.wiley.com/pageljournal/15405885/ homepage/productinformation.html)

An emphasis on cross-functionality and interdisciplinary research was encrypted into the journal's DNA since its inception. In this essay, we explore to what extent JPIM has stayed true to its original mandate and served as a platform for exchange of ideas between different disciplines.

Specifically, we examine how JPIM has influenced other scientific journals and disciplines, and in turn, how much of an impact other scientific journals and disciplines have had on the research published in JPIM over a 20-year period (1994-2013). Biemans, Griffin, and Moenaert (2007) explored some of these knowledge exchange patterns over the first 20 years of JPIM's existence. This essay offers an updated and in-depth analysis of the knowledge outflow and inflow patterns of JPIM. Other journals such as Industrial Marketing Management (Di Benedetto, Sarin, Belkhouja, and Haon, 2018), Journal of the Academy of Marketing Science (Malhotra, 1996), and Journal of International Business Studies (Inkpen and Beamish, 1994) have also engaged in similar introspections over the years.

\section{Methodology}

We employed bibliometric analysis to investigate the impact JPIM has had on other academic journals by 


\section{BIOGRAPHICAL SKETCHES}

Dr. Shikhar Sarin is a professor of marketing at Boise State University (USA) and Waikato Management School, University of Waikato. His research interests include marketing strategy, new product development, innovation, marketing/management of technology, personal selling \& sales management, and digital commerce. He has received research awards from the American Marketing Association, Product Development and Management Association, and the Sales Education Foundation. His research has been published in Journal of Marketing, Journal of Marketing Research, Journal of the Academy of Marketing Science, Decision Sciences, Journal of Product Innovation Management, Industrial Marketing Management, Journal of Marketing Theory and Practice, Journal of Personal Selling and Sales Management, and Engineering Economist, among others.

Dr. Christophe Haon is a professor of marketing at Grenoble Ecole de Management-Université Grenoble Alpes ComUE and a researcher at IREGE (Université Savoie Mont Blanc). He conducts research on marketing strategy, new product development, market orientation, and customer satisfaction. His research has been published in Marketing Letters, Journal of Business Research, Journal of Product Innovation Management, Industrial Marketing Management, and the European Management Review, among others. He has also coauthored several books, including Making Innovation Last: Sustainable Strategies for Long Term Growth, published by Palgrave Macmillan.

Dr. Mustapha Belkhouja is an associate professor of quantitative methods at Grenoble Ecole de Management_Université Grenoble Alpes ComUE. His research topics focus on academic visibility, knowledge diffusion, reputation, and international business. His research has appeared in Journal of Product Innovation Management, Industrial Marketing Management,M@n@ gement, Research Policy, Technological Forecasting \& Social Change, and Strategic Organization, among others.

analyzing how often JPIM is cited by these journals (i.e., knowledge outflow). Similarly, we examine the influence of other academic journals on JPIM (i.e., knowledge inflow) by looking at how often articles published in JPIM cited these journals (Biemans et al., 2007; Di Benedetto et al., 2018; Sarin et al., 2018). For the purpose of this essay, we extracted citation data from every article published in 336 journals in major business disciplines from the Web of Science (WoS). Our bibliometric database contained data on
5,998,130 citations drawn from 135,559 articles published in these journals from 1994 to 2013.

Such citation-based analyses are widely accepted as standard methodology in assessing not only the influence of journals, but also knowledge flow patterns within and among disciplinary domains (e.g., Clark, Key, Hodis, and Rajaratnam, 2014; Nelson, Ham, and Ahn, 2017; Shafiq, 2013). However, such bibliometric analyses are limited in that they are unable to distinguish the level of intellectual indebtedness. They cannot distinguish between citations that truly reflects a transfer of knowledge versus ones that are largely perfunctory (Biemans et al., 2007).

Sarin et al. (2018) further note that journals differ in the number of articles published per year, and the number of references cited per article. Hence in addition to the raw numbers of citations, we adopted the approach recommended by Di Benedetto et al. (2018) and report the citation data in normalized percentage of all references cited in that journal in that year, as recorded in our database. The journal impact factors (IF) were extracted from the Journal Citation Reports (JCR) database from Clarivate Analytics (formerly known as ISI-Institute for Scientific Information).

\section{Findings}

Knowledge Outflow Patterns-Impact of JPIM on Other Journals and Disciplines

JPIM's influence on other journals was measured in terms of the number of times these journals cited JPIM (e.g., Biemans et al., 2007; Sarin et al., 2018). Table 1 presents the list of the Top 50 journals that cited JPIM most frequently over the 1994-2013 period. JPIM was cited 15,756 times over this period in our database of 336 business journals. Of these, 4,300 were self-citations $(27.3 \%)$, and the remaining 11,456 $(72.7 \%)$ citations came from other sources. The 49 other journals listed in Table 1 cited JPIM 9,683 times $(61.5 \%)$. Together, these 50 journals accounted for $88.8 \%$ of all citations received by JPIM from 1994 to 2013.

The Top 50 journals citing JPIM were then categorized in six clusters based on disciplinary domains: Technology and Innovation Management (TIM), Marketing (MKT), Operations Management (OM), Management (MGT), Organization Science (ORG), and Entrepreneurship (ENT). While Table 2 makes a 
Table 1. Identification of the 50 Journals Citing JPIM the Most from 1994 to 2013

\begin{tabular}{|c|c|c|c|}
\hline Journals & $\begin{array}{c}\text { Citations of JPIM } \\
\text { (Incoming Citations) } \\
\text { 1994-2013 }\end{array}$ & $\begin{array}{c}\text { Citations by JPIM } \\
\text { (Outgoing Citations) } \\
\text { 1994-2013 }\end{array}$ & Balance \\
\hline Journal of Product Innovation Management & 4,300 & 4,300 & 0 \\
\hline Industrial Marketing Management & 929 & 450 & 479 \\
\hline Technovation & 892 & 121 & 771 \\
\hline R \& D Management & 722 & 305 & 417 \\
\hline IEEE Transactions on Engineering Management & 664 & 385 & 279 \\
\hline International Journal of Technology Management & 459 & 71 & 388 \\
\hline Journal of Business Research & 420 & 252 & 168 \\
\hline Journal of Engineering and Technology Management & 401 & 114 & 287 \\
\hline Journal of The Academy of Marketing Science & 341 & 422 & -81 \\
\hline Research Policy & 313 & 610 & -297 \\
\hline $\begin{array}{l}\text { International Journal of Operations \& Production } \\
\text { Management }\end{array}$ & 272 & 74 & 198 \\
\hline Journal of Operations Management & 253 & 209 & 44 \\
\hline Creativity and Innovation Management & 244 & 43 & 201 \\
\hline Journal of Marketing & 240 & 2,012 & $-1,772$ \\
\hline Research-Technology Management & 226 & 311 & -85 \\
\hline Technological Forecasting and Social Change & 223 & 38 & 185 \\
\hline Technology Analysis \& Strategic Management & 189 & 32 & 157 \\
\hline Journal of Business \& Industrial Marketing & 187 & 35 & 152 \\
\hline European Journal of Marketing & 173 & 146 & 27 \\
\hline Management Science & 157 & 1,092 & -935 \\
\hline International Journal of Research in Marketing & 146 & 181 & -35 \\
\hline Journal of Marketing Research & 145 & 1,523 & $-1,378$ \\
\hline International Journal of Project Management & 145 & 21 & 124 \\
\hline Journal of International Marketing & 140 & 53 & 87 \\
\hline Decision Sciences & 126 & 100 & 26 \\
\hline Journal of Business Venturing & 109 & 186 & -77 \\
\hline Long Range Planning & 100 & 76 & 24 \\
\hline Journal of Service Management & 95 & 1 & 94 \\
\hline Innovation-Management Policy \& Practice & 90 & 6 & 84 \\
\hline Strategic Management Journal & 78 & 1,468 & $-1,390$ \\
\hline Organization Science & 77 & 668 & -591 \\
\hline International Marketing Review & 74 & 55 & 19 \\
\hline Project Management Journal & 74 & 28 & 46 \\
\hline Journal of Small Business Management & 72 & 21 & 51 \\
\hline Marketing Science & 71 & 373 & -302 \\
\hline Industry and Innovation & 70 & 6 & 64 \\
\hline Journal of Supply Chain Management & 69 & 8 & 61 \\
\hline Marketing Letters & 65 & 67 & -2 \\
\hline Journal of Service Research & 63 & 41 & 22 \\
\hline Asian Journal of Technology Innovation & 57 & 0 & 57 \\
\hline Academy of Management Journal & 57 & 753 & -696 \\
\hline International Journal of Market Research & 56 & 8 & 48 \\
\hline Journal of Services Marketing & 53 & 29 & 24 \\
\hline EMJ-Engineering Management Journal & 51 & 17 & 34 \\
\hline California Management Review & 50 & 349 & -299 \\
\hline Journal of Management \& Organization & 50 & 1 & 49 \\
\hline Supply Chain Management-an International Journal & 50 & 10 & 40 \\
\hline British Journal of Management & 49 & 24 & 25 \\
\hline Journal of Management Studies & 48 & 149 & -101 \\
\hline Journal of Knowledge Management & 48 & 5 & 43 \\
\hline
\end{tabular}

distinction between management, organization science, and entrepreneurship journals, these journals were grouped together in subsequent analyses due to the overlap between their domains.
From Tables 1 and 2 it can be seen that 7 of the Top 10 journals citing JPIM over this period were TIM journals, while the remaining three were marketing. These Top 10 journals accounted for nearly $60 \%$ of 
Table 2. Categorization of Top 50 Journals Citing JPIM by Disciplinary Clusters

\begin{tabular}{|c|c|c|c|c|c|}
\hline $\begin{array}{l}\text { Technology and } \\
\text { Innovation } \\
\text { Management (TIM) }\end{array}$ & Marketing (MKT) & $\begin{array}{l}\text { Operations } \\
\text { Management } \\
(\mathrm{OM})\end{array}$ & $\begin{array}{l}\text { Management } \\
(\text { MGT) }\end{array}$ & $\begin{array}{c}\text { Organization } \\
\text { Science (ORG) }\end{array}$ & $\begin{array}{l}\text { Entrepreneurship } \\
\text { (ENT) }\end{array}$ \\
\hline $\begin{array}{l}\text { Journal of Product } \\
\text { Innovation } \\
\text { Management }\end{array}$ & $\begin{array}{l}\text { Industrial } \\
\text { Marketing } \\
\text { Management }\end{array}$ & $\begin{array}{l}\text { International } \\
\text { Journal of } \\
\text { Operations \& } \\
\text { Production } \\
\text { Management }\end{array}$ & $\begin{array}{l}\text { Management } \\
\text { Science }\end{array}$ & $\begin{array}{l}\text { Organization } \\
\text { Science }\end{array}$ & $\begin{array}{l}\text { Journal of Business } \\
\text { Venturing }\end{array}$ \\
\hline Technovation & $\begin{array}{l}\text { Journal of Business } \\
\text { Research }\end{array}$ & $\begin{array}{l}\text { Journal of } \\
\text { Operations } \\
\text { Management }\end{array}$ & Decision Sciences & $\begin{array}{l}\text { Journal of } \\
\text { Knowledge } \\
\text { Management }\end{array}$ & $\begin{array}{l}\text { Journal of Small } \\
\text { Business } \\
\text { Management }\end{array}$ \\
\hline R \& D Management & $\begin{array}{l}\text { Journal of The } \\
\text { Academy of } \\
\text { Marketing } \\
\text { Science }\end{array}$ & $\begin{array}{l}\text { International } \\
\text { Journal of } \\
\text { Project } \\
\text { Management }\end{array}$ & $\begin{array}{l}\text { Long Range } \\
\text { Planning }\end{array}$ & & \\
\hline $\begin{array}{l}\text { IEEE Transactions } \\
\text { on Engineering } \\
\text { Management }\end{array}$ & $\begin{array}{l}\text { Journal of } \\
\text { Marketing }\end{array}$ & $\begin{array}{l}\text { Journal of Service } \\
\text { Management }\end{array}$ & $\begin{array}{l}\text { Strategic } \\
\quad \text { Management } \\
\text { Journal }\end{array}$ & & \\
\hline $\begin{array}{l}\text { International } \\
\text { Journal of } \\
\text { Technology } \\
\text { Management }\end{array}$ & $\begin{array}{l}\text { Journal of Business } \\
\text { \& Industrial } \\
\text { Marketing }\end{array}$ & $\begin{array}{l}\text { Journal of Supply } \\
\text { Chain } \\
\text { Management }\end{array}$ & $\begin{array}{l}\text { Academy of } \\
\text { Management } \\
\text { Journal }\end{array}$ & & \\
\hline $\begin{array}{l}\text { Journal of } \\
\text { Engineering and } \\
\text { Technology } \\
\text { Management }\end{array}$ & $\begin{array}{l}\text { European Journal } \\
\text { of Marketing }\end{array}$ & $\begin{array}{l}\text { Supply Chain } \\
\text { Management-An } \\
\text { International } \\
\text { Journal }\end{array}$ & $\begin{array}{l}\text { Journal of } \\
\text { Management \& } \\
\text { Organization }\end{array}$ & & \\
\hline Research Policy & $\begin{array}{l}\text { International } \\
\text { Journal of } \\
\text { Research In } \\
\text { Marketing }\end{array}$ & & $\begin{array}{l}\text { California } \\
\text { Management } \\
\text { Review }\end{array}$ & & \\
\hline $\begin{array}{l}\text { Creativity and } \\
\text { Innovation } \\
\text { Management }\end{array}$ & $\begin{array}{l}\text { Journal of } \\
\text { Marketing } \\
\text { Research }\end{array}$ & & $\begin{array}{l}\text { British Journal of } \\
\text { Management }\end{array}$ & & \\
\hline $\begin{array}{l}\text { Research- } \\
\text { Technology } \\
\text { Management }\end{array}$ & $\begin{array}{l}\text { Journal of } \\
\text { International } \\
\text { Marketing }\end{array}$ & & $\begin{array}{l}\text { Journal of } \\
\text { Management } \\
\text { Studies }\end{array}$ & & \\
\hline $\begin{array}{l}\text { Technological } \\
\text { Forecasting and } \\
\text { Social Change }\end{array}$ & $\begin{array}{l}\text { International } \\
\text { Marketing } \\
\text { Review }\end{array}$ & & & & \\
\hline $\begin{array}{l}\text { Technology Analysis } \\
\text { \& Strategic } \\
\text { Management }\end{array}$ & Marketing Science & & & & \\
\hline $\begin{array}{l}\text { Innovation- } \\
\text { Management } \\
\text { Policy \& Practice }\end{array}$ & Marketing Letters & & & & \\
\hline $\begin{array}{l}\text { Project Management } \\
\text { Journal }\end{array}$ & $\begin{array}{l}\text { Journal of Service } \\
\text { Research }\end{array}$ & & & & \\
\hline $\begin{array}{l}\text { Industry and } \\
\text { Innovation }\end{array}$ & $\begin{array}{l}\text { International } \\
\text { Journal of } \\
\text { Market Research }\end{array}$ & & & & \\
\hline $\begin{array}{l}\text { Asian Journal of } \\
\text { Technology } \\
\text { Innovation } \\
\text { EMJ-Engineering } \\
\text { Management } \\
\text { Journal }\end{array}$ & $\begin{array}{l}\text { Journal of Services } \\
\text { Marketing }\end{array}$ & & & & \\
\hline
\end{tabular}

all the citations received by JPIM between 1994 and 2013. Besides self-citations, Technovation (5.7\% of all JPIM citations), $R \& D$ Management (4.6\%), and IEEE
Transaction on Engineering Management (4.2\%) were the TIM journals citing JPIM the most, while Industrial Marketing Management (5.8\%), Journal 
of Business Research (2.7\%), and the Journal of the Academy of Marketing Science (2.2\%) featured prominently among the non-TIM journals in the top quintile of Table 1.

Operations Management journals: International Journal of Production Management (1.7\%) and Journal of Operations Management (1.6\%) make their appearance in the second quintile of Table 1. Surprisingly, management journals (i.e., Management Science, Decision Sciences, Long Range Planning, and Strategic Management Journal) only appear toward the bottom of the second quintile, and in the third quintile of Table 1, with each accounting for less than $1 \%$ of the citations received by JPIM over the 20 -year period. It is worth noting that the journals from the information systems domain are conspicuously absent from the list of top 50 journals citing JPIM.

Next, we examine the evolution in the citation pattern of JPIM over the years. Figure 1 presents the trend in the number of citations of JPIM across the different disciplinary clusters. The numbers of citations of JPIM in the TIM and MKT journals show a steady and large increase from 1994 to 2013, with a significant jump in the number of citations from the TIM journals starting in 2010. The increase in the number of citations is particularly noticeable after 2005 , and coincides with a gradual increase in the number of articles published in JPIM in the previous years (Biemans et al., 2007).

It should be noted that the TIM citation numbers presented in figures are without self-citations. If self-citations were to be included, the trend of JPIM citations in TIM journals would be even more pronounced. The numbers of citations of JPIM in the OM and MGT/ENT/ORG journals also show a steady, albeit much slower increase over this period. However, the numbers of JPIM citations in OM and MGT/ ENT/ORG journals trail the TIM and MKT citations by a wide margin. Overall, the raw numbers of JPIM citations in the OM and MGT/ENT/ORG journals remain low over the period of interest. Not surprisingly, given the growth in the number of citations across the different disciplinary clusters, the JCR Impact Factor for JPIM shows an increasing trend from 1994 to 2013.

Figure 2 presents the trends in the citations of JPIM in different disciplinary clusters in normalized percentage terms. This is done to account for differences between the journals in the number of articles published per year, and the number of references cited per article (Di Benedetto et al., 2018; Sarin et al., 2018).
Figure 2 shows that after accounting for between $40 \%$ and $60 \%$ of all the citations of JPIM in the mid-late 90 s, TIM journals seemed to have settled around $50 \%$ of all JPIM citations starting 2004.

MKT is the second most important citing cluster in Figure 2, holding relatively steady at accounting for about $35 \%$ of all citations of JPIM since 2000, after having recorded as high as $45 \%$ in the late 90 s. There is a slow but steady increase in the percentage of JPIM citations in OM journals, which accounted for about $10 \%$ of all JPIM citations by the end of 2013 . The percentage of JPIM citations in the MGT/ORG/ENT cluster showed a gradual increase in the mid-late 90 s, then decreased steadily from 2001 to 2006 (from $28 \%$ to $5 \%$ ), and has held relatively steady around 10\% since 2008 .

\section{Knowledge Inflow Patterns-Impact of Other Journals and Disciplines on JPIM}

In this section, we focus on how research published in JPIM was influenced by other journals. Not counting self-citation, the other 49 journals identified in Table 1 were cited in JPIM 12,949 times from 1994 to 2013. During this period, the five journals most frequently cited by research published in JPIM were Journal of Marketing (15.5\% of all citations), Journal of Marketing Research (11.7\%), Strategic Management Journal (11.3\%), Management Science (8.4\%), and Academy of Management Journal (5.8\%). Organization Science and Research Policy were also cited quite frequently, accounting for $5.2 \%$ and $4.7 \%$ of the outgoing citations, respectively.

Examining the knowledge inflow by disciplinary clusters reveals that over the 1994-2013 period, studies published in JPIM drew upon MKT journals most heavily ( $43.6 \%$ of all outgoing citations from Table 1$)$, followed by journals in the management/entrepreneurship/organizational (MGT/ENT/ORG) domains $(37.7 \%)$. Articles published in JPIM drew upon TIM (16.1\%) and Operations Management (2.7\%) domains to a much lesser extent. Trends in these outgoing citation patterns over the years provide some additional insights.

Figure 3 presents the trends in citation of the disciplinary clusters in JPIM (in numbers) from 1994 to 2013 . We see an explosion in number of citations in JPIM from 2008 onwards. The vast majority of new citations seem to be coming from articles published in MKT and MGT/ENT/ORG, and to a much lesser extent in the TIM journals. In the last few 


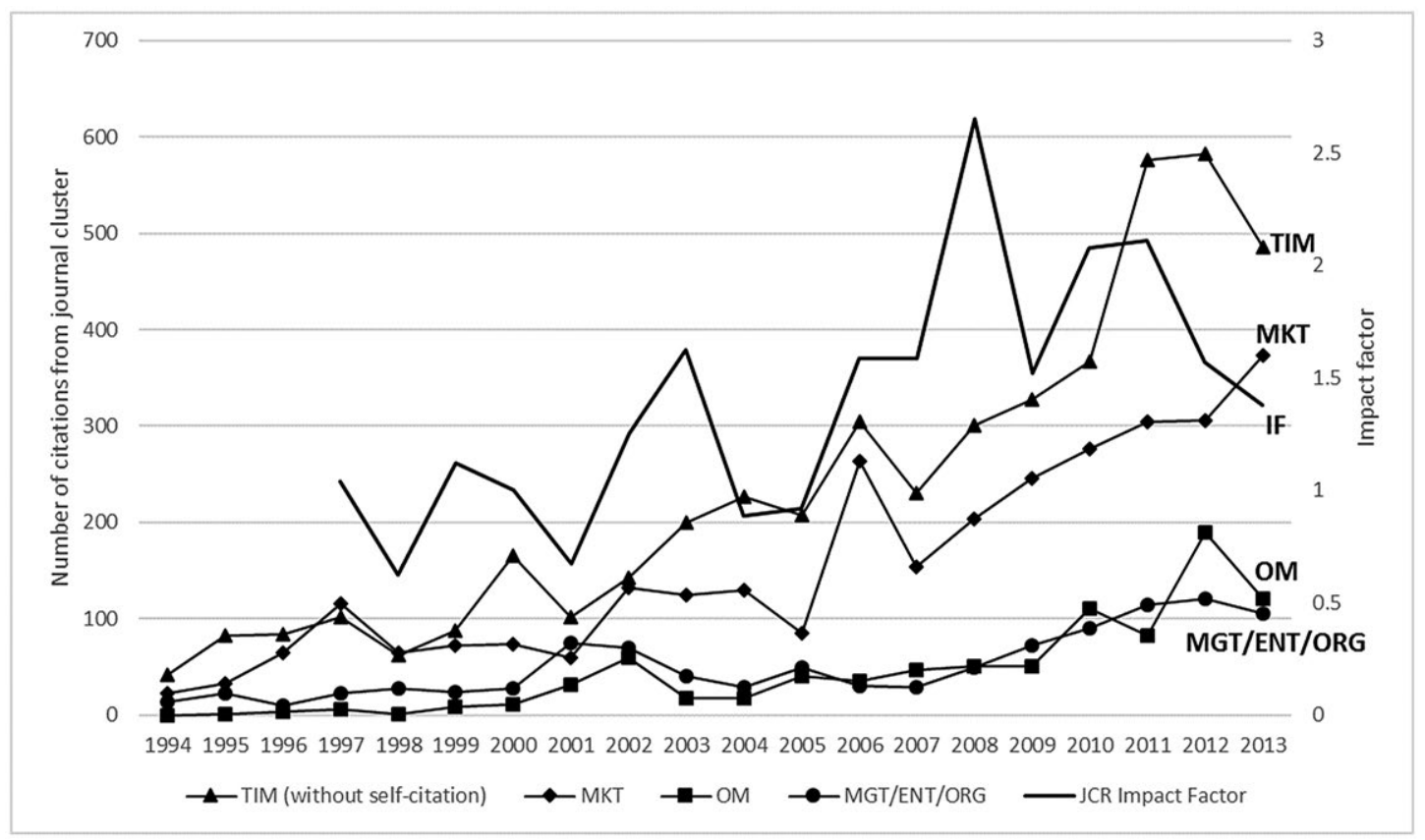

Figure 1. Trends in the Citations of JPIM (in Numbers) by Disciplinary Clusters (1994-2013)

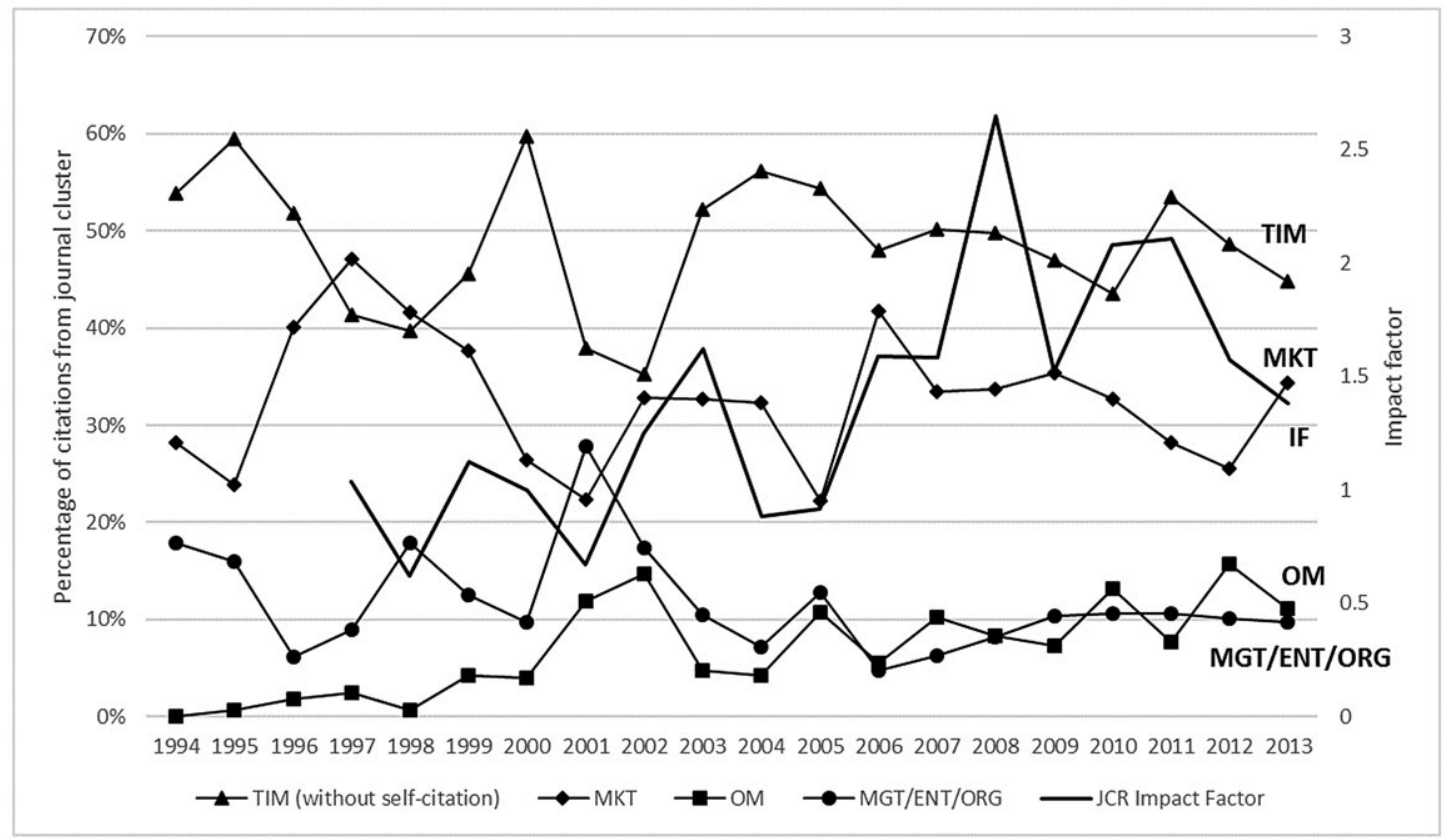

Figure 2. Trends in the Citations of JPIM (in \%) by Disciplinary Clusters (1994-2013)

years of the period under consideration, the rate of increase in outgoing citations for MGT/ENT/ORG seems to be outpacing those from the MKT literature. This suggests an increasing reliance on the body of knowledge from the broader management literature.
The significant jump in citations from MKT and MGT/ENT/ORG starting in 2010 corresponds to a temporary increase in the number of articles published in JPIM from 2010 to 2013. The temporary increase in the number of articles published was necessitated by a need to clear a significant backlog of accepted 


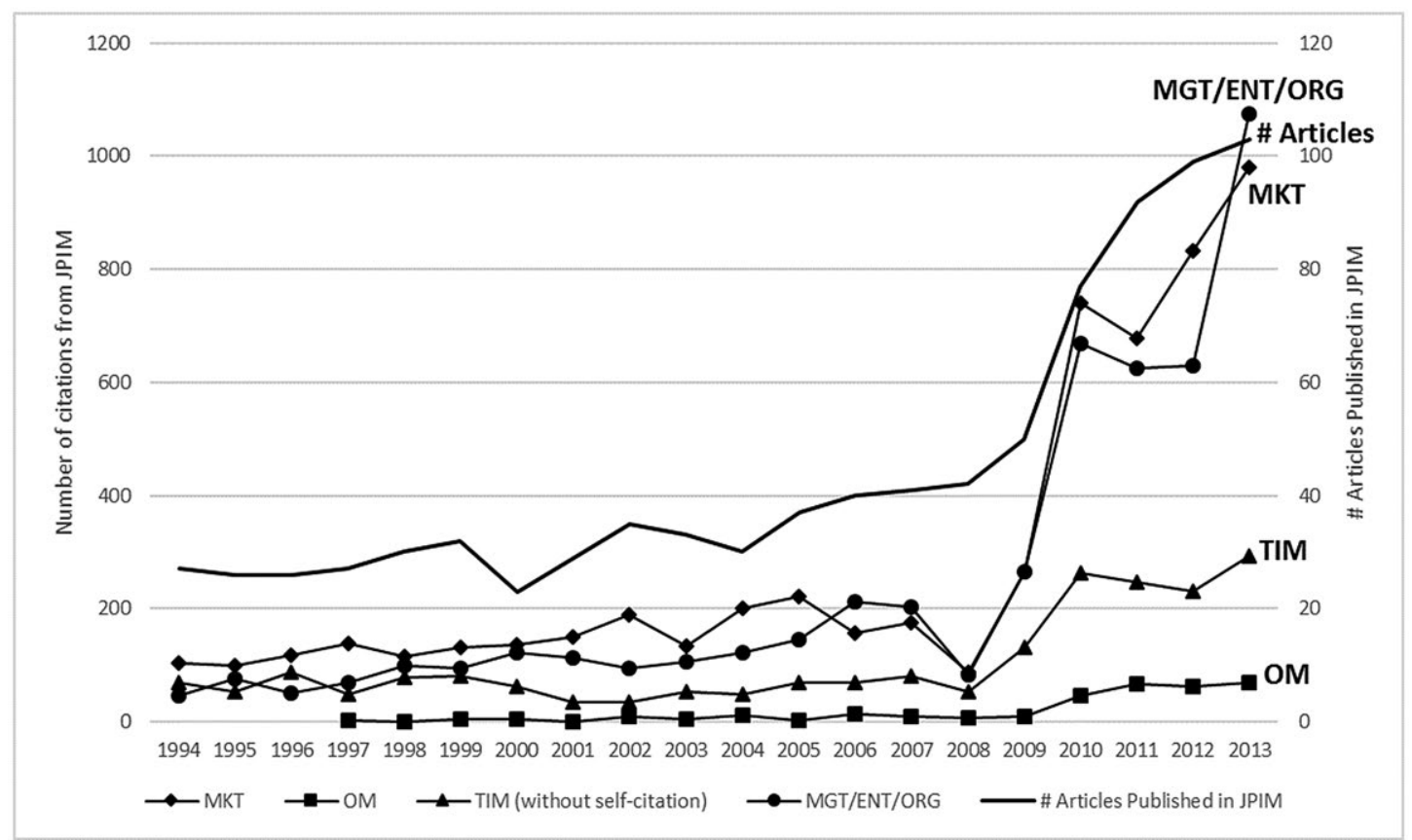

Figure 3. Trends in Citations of Disciplinary Clusters (in Numbers) in JPIM (1994-2013)

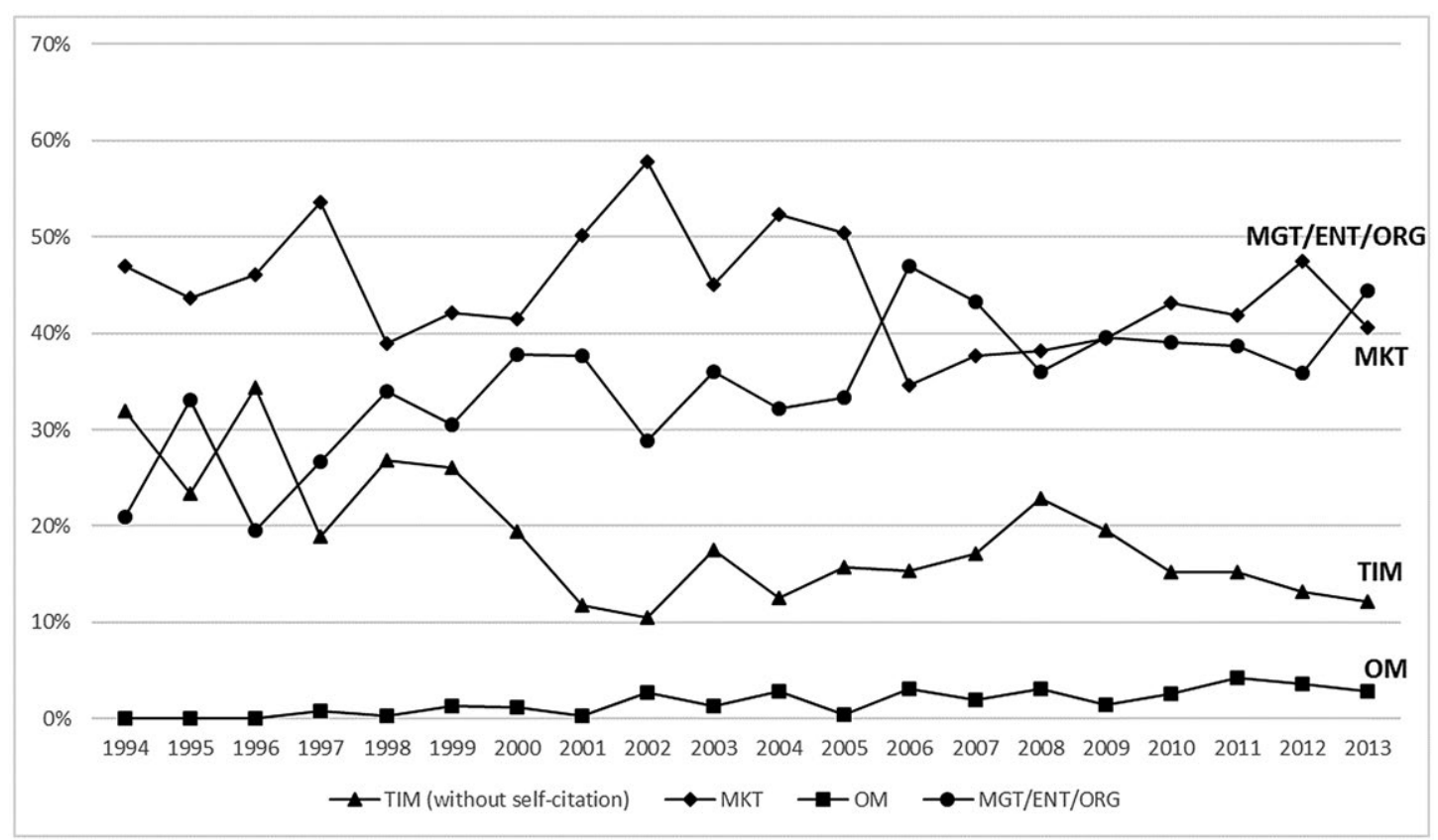

Figure 4. Trend in Citations of Disciplinary Clusters (in \%) in JPIM (1994-2013)

articles and special issues that had been previously approved. ${ }^{1}$

Figure 4 shows the trend in outgoing citations for other disciplines as a percentage of the journals cited in
JPIM. It can be seen that in percentage terms citations from MKT have remained relatively stable between $40 \%$ and $50 \%$. However, citations from the MGT/ENT/ ORG journals have gradually increased from $20 \%$ to

${ }^{1}$ The authors thank Gloria Barczak for this insight. 
around 45\% of the journals cited in JPIM from 1994 to 2013. This coincides with a gradual decline in citation of TIM journals from 33\% in 1994 to $13 \%$ in 2013. While the citation of OM journals increased slightly over the years, its overall level remains low at around $4 \%$.

\section{Net Knowledge Flow Patterns-Difference in Citation Flows to and from JPIM}

Next, we use the data presented in Table 1 to examine the difference between the citations of JPIM by each journal, and the citation of each journal in JPIM from 1994 to 2013. JPIM is regarded as a net importer of knowledge if JPIM cites the journal more frequently (outgoing citations) than it is cited by the journal (incoming citations). On the other hand, JPIM is a net exporter of knowledge to a journal if JPIM is cited by the other journal (incoming citations) more frequently than the other journal is cited in JPIM (outgoing citations).

Over the 20-year period under examination, journals where JPIM is a net exporter of knowledge show a positive balance in the last column of Table 1, and journals where JPIM is a net importer of knowledge show a negative one. Journals to which JPIM has the highest export differential are Technovation, Industrial Marketing Management, and $R \& D$ Management. On the other hand, JPIM has the highest knowledge import differential with Journal of Marketing, Journal of Marketing Research, and Strategic Management Journal.

Table 3 presents a year-by-year analysis of the number of citations of JPIM minus the number of citations by JPIM for each disciplinary cluster. Again, a net export situation reflects in a positive balance, and a net import situation in a negative one. Increasingly, JPIM seems to be acting as a gatekeeper, importing heavily from MKT and MGT/ENT/ORG, and exporting more and more to other TIM journals (and OM journals to a lesser extent).

A graph of this data, presented in Figure 5, shows that JPIM's net knowledge deficit with MKT and MGT/ENT/ORG increased substantially starting 2008. The net knowledge deficit with MGT/ENT/ORG seems to be increasing at a more rapid rate than MKT.

\section{Implications}

This essay conducted a 20-year bibliometric analysis of the knowledge outflow and inflow patterns from JPIM using a database containing nearly 6 million citations drawn from over 135,000 articles published

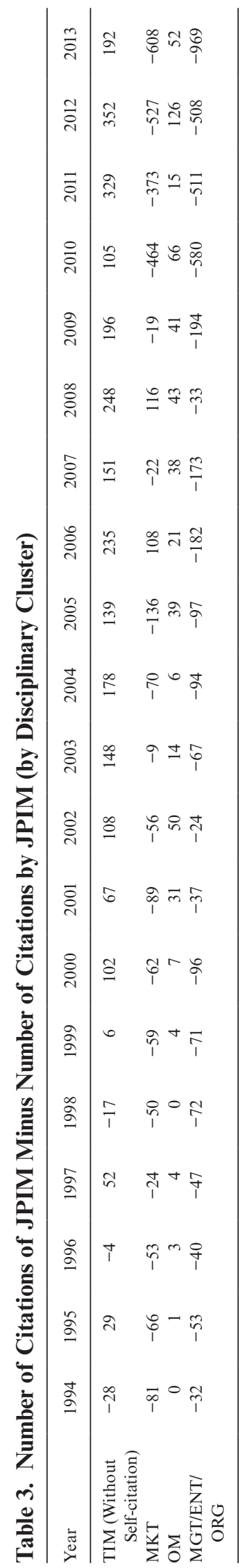




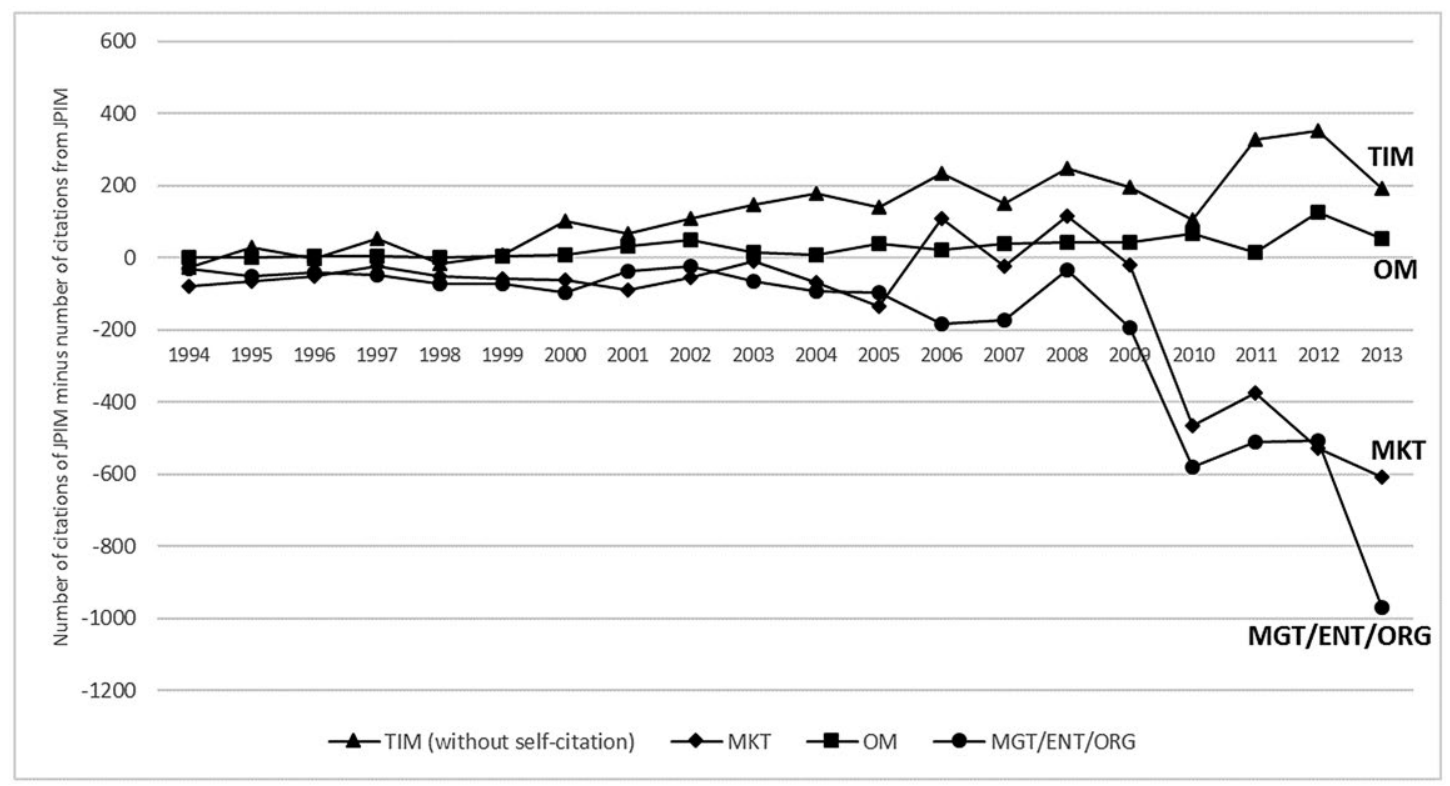

Figure 5. Trends in the Difference Between Citation Flows to and From JPIM (1994-2013)

in 336 major business journals. Our findings suggest that JPIM has made significant strides toward fulfilling its mandate to serve as an interdisciplinary platform for exchange of ideas on new product development and innovation management. However, work remains to be done.

A significant number of the JPIM's knowledge outflow (i.e., JPIM's impact) from 1994 to 2013 came from TIM and MKT journals, and to much lesser extent $\mathrm{OM}$ and MGT/ENT/ORG journals. This is not surprising given that a majority of the authors publishing in JPIM during this period came from a marketing background (Biemans et al., 2007). While both OM and MGT/ENT/ORG journals have shown a very slow uptick in their citations of research published in JPIM, the percentage of JPIM citations coming from MGT/ENT/ORG journals has gone down slightly over time. Both OM and MGT/ENT/ORG journals only accounted for a relatively modest percentage of overall citations of JPIM from 1994 to 2013.

This is somewhat surprising, given the obvious synergy between the ENT and TIM domains. Additionally, a lot of research published in JPIM relates to organizational and team-related factors affecting innovation-subjects that should be of inherent interest to the strategy, organization science, and organizational behavior literatures (Biemans et al., 2007). Another surprising finding of our analysis was the noticeable absence of Management Information Systems (MIS) journals from the list of the Top 50 journals citing JPIM most frequently over the 1994-2013 period. This suggests that while JPIM has done an outstanding job of disseminating its knowledge in the TIM and MKT disciplines, significant outreach work remains to be done in the OM, MGT/ENT/ORG, and MIS domains. JPIM needs to be more proactive in reaching out to scholars in these domains.

We would encourage the incoming JPIM editorial team to consider commissioning innovation-related special issues at the intersection of OM, MGT/ENT/ ORG, and MIS to encourage scholars in these areas to publish in JPIM. Efforts should also be made to recruit and invite leading scholars in these domains to publish influential thought pieces in JPIM. This in turn would increase the visibility of JPIM in these domains.

Knowledge inflow patterns (i.e., the impact of other journals/disciplines on JPIM) from 1994 to 2013 suggest a maturing of the knowledge base from which JPIM draws upon. Over the period under examination, research published in JPIM came to rely upon other TIM journals less and less. While the total number of TIM citations in JPIM have grown modestly, their share of the outgoing citations has gone down steadily over the years. Since 2008, JPIM seems to have moved significantly in drawing upon MKT and MGT/ENT/ORG domains, and presumably upon more basic and established theories. Reliance 
on MGT/ENT/ORG journals seems to be fast outpacing the reliance on the MKT journals in recent years. A more detailed breakdown of the MGT/ENT/ ORG cluster shows that most of the knowledge inflow seems to be concentrated on the management journals, rather than the ORG and ENT journals.

Once again, the relative isolation of JPIM from the ENT journals is somewhat surprising. One possible explanation can be that despite its stated openness to research on start-ups and small/medium businesses, a majority of the research published in JPIM concentrates on large organizations. Journals in the OM domain seem to have a negligible influence on the research published in JPIM.

Over the last 20 years, JPIM has firmly established itself as a highly influential forum for knowledge exchange in the TIM domain. It often acts as a gatekeeper in this domain, importing more net knowledge from MKT and MGT/ENT/ORG domains, and exporting them to the TIM journals (and OM journals to a lesser extent). As JPIM strides toward being universally regarded as the premier multidisciplinary journal in new product development and innovation management, it will benefit greatly from casting a wider net to appeal to a broader community of innovation scholars.

\section{References}

Biemans, W., A. Griffin, and R. Moenaert. 2007. Twenty years of the Journal of Product Innovation Management: History, participants, and knowledge stock and flows. Journal of Product Innovation Management 24 (3): 193-213.

Clark, T., T. M. Key, M. Hodis, and D. Rajaratnam. 2014. The intellectual ecology of mainstream marketing research: An inquiry into the place of marketing in the family of business disciplines. Journal of the Academy Marketing Science 42 (3): 223-41.

Di Benedetto, A., S. Sarin, M. Belkhouja, and C. Haon. 2018. Patterns of knowledge outflow from Industrial Marketing Management to major marketing and specialized journals (1999-2013): A citation analysis. Industrial Marketing Management 69: 13-17.

Inkpen, A. C., and P. W. Beamish. 1994. An analysis of twenty-five years of research in the Journal of International Business Studies. Journal of International Business Studies 25 (4): 703-13.

Linton, J., and N. T. Thongpapanl. 2004. Ranking the technology innovation management journals. Journal of Product Innovation Management 21 (2): 123-39.

Malhotra, N. K. 1996. The impact of the Academy of Marketing Science on marketing scholarship: An analysis of the research published in JAMS. Journal of the Academy of Marketing Science 24 (4): 291-98.

Nelson, M. R., C. Ham, and R. Ahn. 2017. Knowledge flows between advertising and other disciplines: A social exchange perspective. Journal of Advertising 46 (2): 309-32.

Sarin, S., C. Haon, and M. Belkhouja. 2018. A bibliometric analysis of the knowledge exchange patterns between major technology and innovation management journals (1999-2013). Journal of Product Innovation Management 35 (1): 2-98.

Shafiq, M. 2013. Thinking inside the box? Intellectual structure of the knowledge base of innovation research (1988-2008). Strategic Management Journal 34 (1): 62-93. 